\title{
PENGARUH RASIO KEUANGAN, UKURAN PERUSAHAAN DAN CORPORATE SOCIAL RESPONSIBILITY TERHADAP AGRESIVITAS PAJAK PADA PERUSAHAAN MANUFAKTUR YANG TERDAFTAR DI BURSA EFEK INDONESIA
}

\author{
Diah Ayu Lestari', Alfiyani Nur Hidayanti ${ }^{2}$ \\ Program Studi Akuntansi, Fakultas Ekonomi dan Bisnis, Universitas Muria Kudus \\ 1diahayulestari77@gmail.com \\ 2alfiyani.nur@umk.ac.id
}

\begin{abstract}
ABSTRAK
Penelitian ini bertujuan untuk menganalisis pengaruh rasio keuangan, ukuran perusahaan dan corporate social responsibility terhadap agresivitas pajak pada perusahaan manufaktur yang terdaftar di Bursa Efek Indonesia (BEI) tahun 2013-2016. Jenis penelitian ini bersifat kuantitatif dengan menggunakan data sekunder berupa data laporan keuangan dari berusahaan yang diperoleh dari www.idx.com dan sumber lain yang relevan. Populasi pada penelitian ini yaitu seluruh perusahaan manufaktur yang terdaftar di Bursa Efek Indonesia (BEI) pada tahun 2013-2016. Penentuan sampel menggunakan metode purposive sampling dan diperoleh sampel sebanyak 37 perusahaan dengan jumlah observasi sebanyak 148 sampel $(37 \mathrm{x} 4)$. Teknik analisis data dalam penelitian ini menggunakan analisis regresi linear berganda. Hasil penelitian menunjukkan bahwa leverage berpengaruh positif dan signifikan terhadap agresivitas pajak, likuiditas berpengaruh negatif dan signifikan terhadap agresivitas pajak, profitabilitas berpengaruh positif dan signifikan terhadap agresivitas pajak, ukuran perusahaan tidak berpengaruh terhadap agresivitas pajak dan corporate social responsibility berpengaruh negatif dan signifikan terhadap agresivitas pajak.
\end{abstract}

Kata Kunci: Rasio Keuangan, ukuran perusahaan, corporate social responsibility dan agresivitas pajak.

\section{ABSTRACT}

This study aims to analyze effect of financial ratio, firm size and corporate social responsibility to the tax aggressiveness at manufacturing companies listed in Indonesia Stock Exchange (BEI) in 2013-2016. The type of research is quantitative by using secondary data in the form of financial statement data from companies obtained from www.idx.com and other relevant sources. The population in this study is all manufacturing companies listed in the Indonesia Stock Exchange (IDX) in the year 2013-2016. Determination of the sample using purposive sampling method and obtained a sample of 37 companies with the number of observations as many as 148 samples (37x4). Data analysis techniques in this study using multiple linear regression analysis denggan using SPSS 23 program assistance. The result of the research shows that leverage have positive and significant effect to tax aggressiveness, liquidity have negative and significant effect to tax aggressiveness, profitability have positive and significant effect to tax aggressiveness, the firm size does not have effect to tax 
aggressiveness and corporate social responsibility have negative and significant effect on tax aggressiveness.

Keywords: financial ratio, firm size, corporate social responsibility and tax aggressiveness.

\section{PENDAHULUAN}

Perpajakan sering menjadi permasalahan yang dihadapi perusahaan. Sebab, perusahaan ingin membayar pajak dengan jumlah yang sedikit. Pajak merupakan salah satu yang menjadi sumber pendapatan negara yang terpenting di Indonesia. Di negara Indonesia penerimaan pajak pada tahun 2010-2014 baru sekitar 72-78\%. Realisasi penerimaan pph yang tidak sesuai dengan target dikarenakaan perusahaan meminimalisir beban pajak yang harus dibayarkan. Perusahaan menekan biaya dengan meminimalisir kewajiban dalam membayar pajak, karena perusahaan menganggap beban pajak akan mengurangi laba setelah pajak, tingkat pengembalian dan arus kas (Suandy,2011:5).

Menurut pendapat Frank, et al. (2009), agresivitas pajak perusahaan merupakan suatu tindakan rekayasa pendapatan kena pajak yang dipersiapkan dengan tidakan perencanaan pajak (tax planning) baik memakai cara yang yang legal (tax avoidance) atau ilegal (tax evasion). Meskipun tidak semua tindakan dianggap melanggar peraturan, tapi semakin banyak celah yang dipakai atau dianggap semakin besar melakukan penghematan maka perusahaan tersebut dianggap semakin agresif dalam pajak. Faktor-faktor yang dianggap berpengaruh terhadap agresivitas yaitu rasio keuangan (leverage, likuiditas, dan profitabilitas), ukuran perusahaan dan corporaate social responsibility (Surbakti, 2012).

Beberapa peneliti terdahulu yang berkaitan dengan agresivitas pajak antara lain penelitian yang dilakukan oleh Hanik dan Fadjrih (2016) menunjukkan bahwa corporate social responsibility berpengaruh signifikan dan negatif terhadap agresivitas pajak. Sedangkan penelitian dari Fitri Anita (2015) menunjukkan bahwa corporate social responsibility tidak berpengaruh terhadap agresivitas pajak. Penelitian yang dialakukan Hanik L.K dan Nur F.A (2016) menyatakan bahwa leverage berpengaruh terhadap agresivitas pajak. Sedangkan penelitian yang dilakukan oleh Fitri Anita (2015) menyatakan bahwa leverage tidak berpengaruh terhadap agresivitas pajak. Menurut penelitian dari Tiaras dan Wijaya (2015) menyatakan bahwa likuiditas tidak berpengaruh terhadap agresivitas pajak. Sedangkan menurut penelitian dari dan Fitri Anita (2015) yang menyatakan bahwa likuiditas berpengaruh terhadap agresivitas pajak. Menurut penelitian Luke dan Zulaikha (2016) dan Tiaras dan Wijaya (2015), menyatakan bahwa ukuran perusahaan (Size) berpengaruh posistif terhadap agresivitas pajak. Menurut penelitian yang dilakukan oleh Luke dan Zulaikha (2016) dan 
Hengky R (2015) menyatakan bahwa profitabilitas berpengaruh positif signifikan terhadap agresivitas pajak.

Penelitian ini merupakan replikasi dari penelitian yang dilakukan oleh Hanik dan Fadjrih (2016) penelitiannya menggunakan empat variabel yang mempengaruhi agresivitas pajak yaitu corporate social responsibility, leverage, ukuran perusahaan, dan capital intensity.

Perbedaan penelitian ini dengan peneliti yang dilakukan Hanik L.K dan Nur F.A (2016) yaitu terdapat pada variabel, ada yang dihapus dan ditambahkan serta tahun penelitian. Penambahan tiga variabel yaitu likuiditas dan profitabilitas. Motivasi peneliti menambah variabel yaitu karena masih banyak faktor yang berpengaruh serta berkontribusi terhadap agresivitas pajak, peneliti juga bermaksud untuk memahami seberapa besar pengaruh tiap variabel terhadap agresivitas pajak pada perusahaan manufaktur.

Berdasarkan latar belakang yang sebelumnya telah diungkap maka peneliti mengkasi perumusan maslah sebagai berikut: (1) Apakah leverage berpengaruh terhadap agresivitas pajak? (2) Apakah likuiditas berpengaruh terhadap agresivitas pajak? (3) Apakah profitabilitas berpengaruh terhadap agresivitas pajak? (4) Apakah ukuran perusahaan (Size) berpengaruh terhadap agresivitas pajak? (5) Apakah corporate social responsibility berpengaruh terhadap agresivitas pajak?. Tujuan dari ppenelitian ini yaitu (1) Untuk mengetahui pengaruh leverage terhadap agresivitas pajak (2) Untuk menguji pengaruh likuiditas terhadap agresivitas pajak (3) Untuk mengetahui apakah profitabilitas berpengaruh terhadap agresivitas pajak (4) Untuk menguji pengaruh ukuran perusahaan terhadap agresivitas pajak (5) Untuk mengetahui pengaruh corporate social responsibility terhadap agresivitas pajak.

\section{TINJAUAN TEORITIS}

\section{Teori Legitimasi}

Teori legitimasi menjelaskan tentang kontrak sosial suatu organisasi dengan masyarakat, kelangsungan hidup suatu perusahaan dapat terancam apabila masyarakat merasa organisasi sudah melanggar kontrak sosialnya. Legitimasi yaitu keadaan psikologis dari orang dan kelompok yang berpihak dan sangat peka pada gejala lingkungan sekitar fisik ataupun non fisik (Hanik L.K dan Nur F.A, 2016).

\section{Teori Agensi}

Teori agensi merupakan teori yang menjelaskan adanya hubungan antara pihak yang memberikan wewenang (prisipal) dan pihak yang menerima wewenang (agent). Seperti halnya sifat dari seorang manusia yang akan selalu mementingkan diri sendiri dibandingkan 
kepentingan oranglain, hal itu akan mendorong manusia untuk bertindak untuk kepentingan sendiri (Budi Rohmansyah, 2016).

\section{Agresivitas Pajak}

Menurut Yoehana (2013: 5) agresivitas pajak yaitu kemauan perusahaan untuk meminimalisir beban pajak dengan tax planning yang bertujuan memaksimalkan nilai dari perusahaan. Dapat disimpulkan dari berbagai pendapat diatas bahwa agresivitas pajak adalah salah satu cara perusahaan untuk meminimalkan beban pajak baik dengan cara legal maupun ilegal. Ada banyak cara untuk mengukur agresivitas pajak, antara lain menggunakan proksi Effective Tax Rates (ETR), Book Tax Differences (BTD), Discretionary Permanent (DTAX), Unrecognize Tax Benefit, Tax Shelter Activity dan Marginal Tax Rate.

\section{Leverage}

Leverage merupakan rasio yang digunakan untuk mengukur sejauh mana aktiva perusahaan yang dibiayai oleh hutang (Kasmir, 2011: 151). Penggunaan leverage dapat meningkatkan laba untuk pemegang saham. Sebaliknya leverage juga dapat menambah risiko keuntungan, sebab jika perusahaan ternyata memperoleh laba lebih kecil dari beban tetapnya maka penggunaan leverage akan mengurangi laba yang akan diperoleh pemegang saham.

\section{Likuiditas}

Menurut Kasmir (2011: 129) rasio likuiditas yaitu rasio yang menggambarkan kemampuan suatu perusahaan untuk memenuhi hutang jangka pendek (Fred Weston). Rasio likuiditas merupakan rasio yang digunakan untuk mengukur seberapa likuidnya suatu perusahaan. Penilaian dapat dilakukan untuk beberapa periode sehingga dapat terlihat perkembangan likuiditas perusahaan dari waktu ke waktu.

\section{Profitabilitas}

Profitabilitas menggambarkan kemampuan perusahaan untuk mendapatkan laba dalam hubungannya dengan penjualan, total aktiva maupun modal sendiri (Sartono, 2010: 122).

\section{Ukuran Perusahaan}

Ukuran perusahaan menggambarkan besar dan kecilnya aset (harta) yang dimiliki perusahaan. Semakin besar suatu perusahaan juga semakin memiliki aktivitas operasi yang semakin tinggi. Perusahaan yang besar tentu mempunyai pengalaman yang lebih banyak dalam kegiatan operasional dan mempunyai kematangan lebih dalam strategi guna kelangsungan operasinya, termasuk strategi dalam penghematan beban pajak (Kristanto, 2013). 


\section{Corporate Social Responsibility}

Corporate Social Responsibility yaitu salah satu kegiatan yang harus dilakukan oleh perusahaan yang menginginkan kegiatan usaha yang dilakukan dapat berjalan lancar serta berkesinambungan. Landasan yang menjadi dasar tanggung jawab sosial adalah bagaimana perusahaan tersebut bersimpati pada lingkungan, terhadap dampak yang diakibatkan oleh aktivitas operasional perusahaan. (Suparnyo, 2010: 122).

\section{Kerangka Pemikiran}

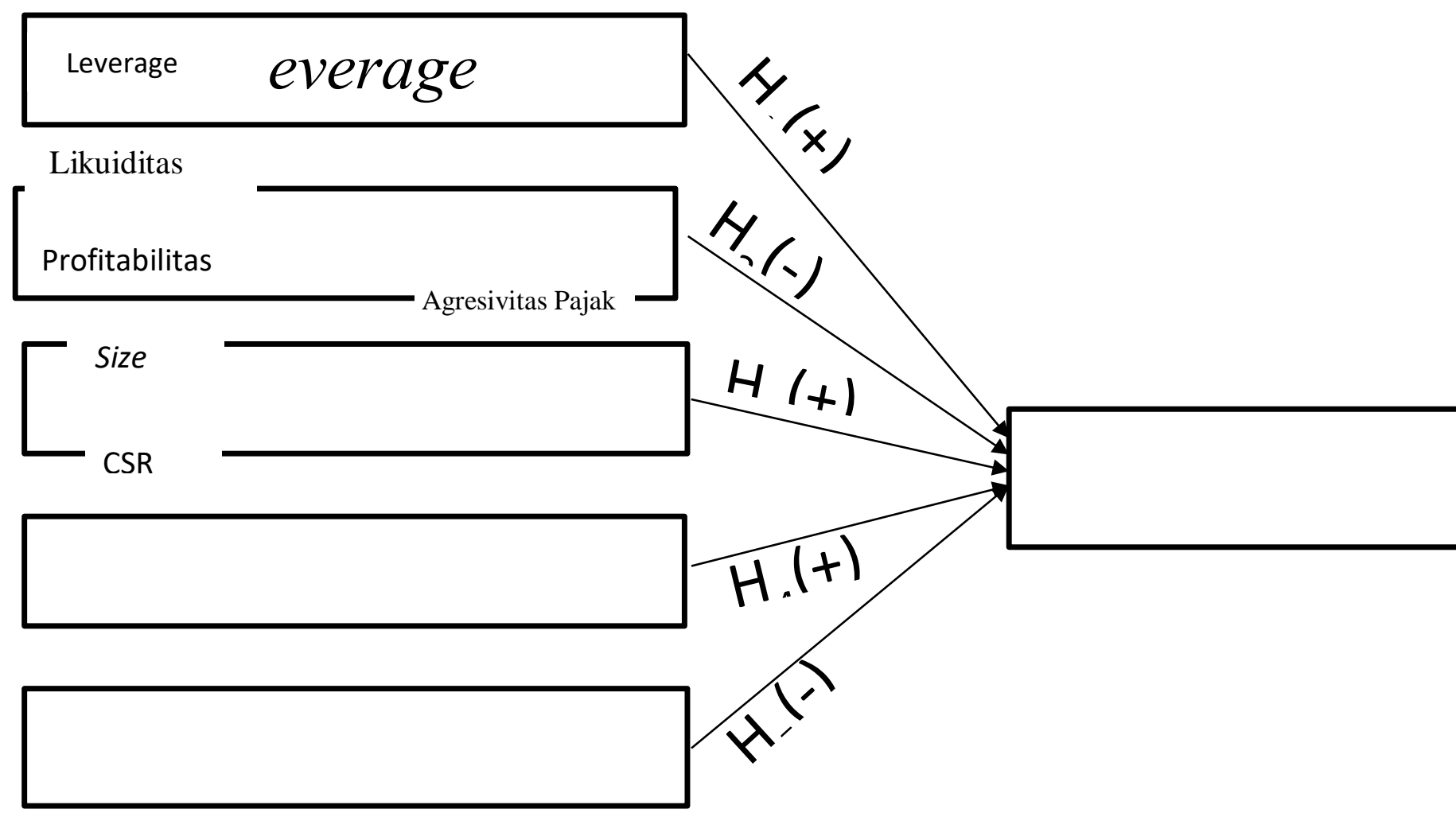

Sumber: Hanik dan Fadjrih (2016), Fitri Anita (2015) dan Hengky R (2016) yang telah dimodifikasi.

\section{Hipotesis Penelitian}

H1: Leverage berpengaruh positif terhadap agresivitas pajak.

$\mathrm{H} 2$ : Likuiditas berpengaruh negatif terhadap agresivitas pajak.

H3: Profitabilitas berpengaruh positif terhadap agresivitas pajak.

H4: Ukuran perusahaan (Size) berpengaruh positif terhadap agresivitas pajak.

H5: Pengungkapan corporate social responsibility berpengaruh negatif terhadap agresivitas pajak.

\section{METODE PENELITIAN}

Penelitian ini dilakukan pada perusahaan manufaktur yang terdaftar di Bursa Efek Indonesia pada tahun 2013-2016. Sumber data yang digunakan adalah jenis data sekunder 
yang diperoleh dari laporan keuangan perusahaan (www.idx.co.id). Teknik pengambilan sampel menggunakan metode purposive sampling. Pengolahan datanya menggunakan program Statistic Package for Social Sciences (SPSS) 23 for windows. Alat anlisis yang digunakan yaitu metode statistik deskriptif, uji asumsi klasik, uji regresi linear berganda dan pengujian hipotesis.

\section{HASIL PENELITIAN}

\section{Statistik deskriptif}

Menurut Ghozali (2016: 19) statistik deskriptif memberikan gambaran atau deskripsi suatu data yang dilihat dari nilai rata-rata (mean), standar deviasi, varian, maksimum, minimum, sum, range, kurtosis serta skewness (kemencengan distribusi). Hasil penelitian uji analisis statistik deskriptif dapat dilihat pada tabel 4.1

Tabel 4.1

Uji Statistik Deskriptif

Descriptive Statistics

\begin{tabular}{|l|r|r|r|r|r|r|}
\hline & \multicolumn{1}{|c|}{$\mathrm{N}$} & \multicolumn{1}{c|}{ Min } & \multicolumn{1}{c|}{ Max } & \multicolumn{1}{c|}{ Sum } & \multicolumn{1}{c|}{ Mean } & \multicolumn{1}{c|}{ Std. Deviation } \\
\hline Leverage & 148 &, 07 &, 88 & 62,88 &, 4249 &, 17178 \\
Likuiditas & 148 & 1,02 & 3,96 & 324,36 & 2,1916 &, 62222 \\
Profitabilitas & 148 &, 02 &, 22 & 14,73 &, 0995 &, 04179 \\
Ukuran Perusahaan & 148 & 16,39 & 23,48 & 2783,65 & 18,8084 & 2,03875 \\
CSR & 148 &, 18 &, 65 & 61,96 &, 4186 &, 09896 \\
Agresivitas Pajak & 148 &, 06 &, 71 & 42,72 &, 2886 &, 10345 \\
Valid N (listwise) & 148 & & & & & \\
\hline
\end{tabular}

Sumber: Data yang diolah 2018

Berdasarkan tabel diatas diketahui jumlah data yang valid pada penelitian ini yaitu 148 sampel. Berikut adalah hasil analisis statistik deskriptif:

Variabel leverage memiliki nilai minimum sebesar 0,07 dan nilai maksimum 0,88. Nilai mean 0,4249 lebih besar dari nilai std. Deviation yaitu 0,17178 artinya penyebaran data pada variabel leverage dianggap sudah menyeluruh dan bervariasi.

Variabel likuiditas memiliki nilai minimum sebesar 1,02 dan nilai maksimum 3,96. Nilai mean 2,1916 lebih besar dari nilai std. Deviation yaitu 0,62222 artinya penyebaran data pada variabel likuiditas dianggap sudah menyeluruh dan bervariasi. 
Variabel profitabilitas memiliki nilai minimum sebesar 0,02 dan nilai maksimum 0,22 . Nilai mean 0,0995 lebih besar dari nilai std. Deviation yaitu 0,04179 artinya penyebaran data pada variabel profitabilitas dianggap sudah menyeluruh dan bervariasi.

Variabel ukuran perusahaan memiliki nilai minimum sebesar 16,39 dan nilai maksimum 23,48. Nilai mean 18,8084 lebih besar dari nilai std. Deviation yaitu 2,03875 artinya penyebaran data pada variabel ukuran perusahaan dianggap sudah menyeluruh dan bervariasi.

Variabel corporate social responsibility memiliki nilai minimum sebesar 0,18 dan nilai maksimum 0,65. Nilai mean 0,4186 lebih besar dari nilai std. Deviation yaitu 0,09896 artinya penyebaran data pada variabel corporate social responsibility dianggap sudah menyeluruh dan bervariasi.

Variabel agresivitas pajak memiliki nilai minimum sebesar 0,06 dan nilai maksimum 0,71. Nilai mean 0,2886 lebih besar dari nilai std. Deviation yaitu 0,10345 artinya penyebaran data pada variabel agresivitas pajak dianggap sudah menyeluruh dan bervariasi.

\section{Uji Asumsi Klasik}

Uji asumsi klasik memiliki tujuan yaitu untuk mengetahui kelayakan penggunaan model regresi dalam penelitian ini. Pengujian asumsi klasik meliputi uji normalitas, uji autokorelasi, uji multi kolinearitas dan uji heterokedastisitas.

\section{Uji Normalitas}

Tujuan dari uji normalitas yaitu untuk menguji apakah pada model regresi, variabel pengganggu atau residual memiliki distribusi normal (Ghozali, 2016: 154). Uji normalitas pada penelitian ini menggunakan uji normal Kolmogrov-Smirnov. Jika variabel mempunyai statistik Kolmogrov-Smirnov signifikan $(\mathrm{p}>0,05)$ maka variabel tersebut mempunyai distribusi normal. Hasil uji normalitas dapat dilihat pada tabel 4.2

Tabel 4.2

Uji Normalitas

One-Sample Kolmogorov-Smirnov Test

\begin{tabular}{|ll|r|}
\hline & & $\begin{array}{c}\text { Unstandardize } \\
\text { d Residual }\end{array}$ \\
\hline $\mathrm{N}$ & Mean & 148 \\
Normal & Std. &, 0000000 \\
Parameters ${ }^{\mathrm{a}, \mathrm{b}}$ & Deviation &, 08777404 \\
Most Extreme & Absolute &, 097 \\
Differences & Positive &, 097 \\
& Negative &,- 064
\end{tabular}




$$
\begin{array}{|l|r|}
\text { Test Statistic } & , 097 \\
\text { Asymp. Sig. (2-tailed) } & , 072^{\mathrm{c}} \\
\hline
\end{array}
$$

Sumber: Data yang diolah 2018

Berdasarkan hasil uji normalitas diketahui nilai probabilitas sebesar 0,072, artinya nilai probabilitas > 0,05. Maka dapat disimpulkan bahwa data penelitian ini berdistribusi normal.

\section{Uji Autokorelasi}

Tujuan dari uji autokorelasi yaitu menguji apakah suatu model regresi linear, korelasi antara kesalahan penggangu pada periode $\mathrm{t}$ dengan kesalahan pengganggu pada periode $\mathrm{t}-1$ (sebelumnya) Ghozali (2016: 107). Penelitian ini menggunakan uji Durbin Watson (DW). Tdk ada auto korelasi, positif atau negatif jika $\mathrm{du}<\mathrm{d}<4-\mathrm{du}$. Hasil uji autokorelasi dapat dilihat pada tabel 4.3

Tabel 4.3

Uji Autokorelasi

\begin{tabular}{|l|r|}
\hline \multicolumn{2}{|c|}{ Model Summary $^{\mathbf{b}}$} \\
\hline Model & Durbin-Watson \\
\hline 1 & 1,861 \\
\hline
\end{tabular}

Sumber: Data yang diolah 2018

Berdasarkan hasil uji autokorelasi dengan uji Durbin-Watson diketahui nilai dw sebesar 1,861, artinya nilai DW berada diantara $d U=1,8016$ sampai $4-d U=2,1984$. Maka dapat disimpulkan nilai $\mathrm{dU}<\mathrm{DW}<4-\mathrm{dU}$ artinya data pada penelitian ini bebas dari autokorelasi.

\section{Uji Multikolinearitas}

Tujuan dari uji multikolineariras yaitu menguji apakah model regresi ditemukan adanya korelasi antar variabel independen. Nilai cutoff yang umum dipakai untuk menunjukkan adanya multikolonieritas adalah nilai Tolerance $\leq 0,10$ atau sama dengan nilai VIF $\geq 10$ (Ghozali, 2016: 103-104). Hasil uji multikolinearitas dapat dilihat pada tabel 4.4

Tabel 4.4

Uji Multikolinearitas

Coefficients $^{\mathbf{a}}$

\begin{tabular}{|l|l|l|}
\hline \multirow{2}{*}{ Model } & \multicolumn{2}{|c|}{ Collinearity Statistics } \\
\cline { 2 - 3 } & Tolerance & VIF \\
\hline $1 \quad$ (Constant) & & \\
\hline
\end{tabular}




\begin{tabular}{|l|r|r|}
\hline Leverage &, 808 & 1,238 \\
Likuiditas &, 802 & 1,247 \\
Profitabilitas &, 910 & 1,099 \\
Ukuran Perusahaan &, 985 & 1,015 \\
CSR &, 971 & 1,030 \\
\hline
\end{tabular}

Sumber: Data yang diolah 2018

Berdasarkan tabel diatas diketahui bahwa semua variabel independen memiliki nilai tilerance $>0,10$ dan nilai VIF $<10$. Maka dapat disimpulkan bahwa data pada penelitian ini bebas dari multikolinearitas.

\section{Uji Heteroskedastisitas}

Uji heteroskedastis memiliki tujuan yaitu menguji apakah dalam model regresi terjadi ketidaksamaan variance dari residual satu pengamatan ke pengamatan lain (Ghozali, 2016: 134). Penelitian ini menggunakan uji glejser. Glejser mengusulkan untuk meregres nilai absolut residual terhadap variabel independen. Apabila variabel independen signifikan secara statistik mempengaruhi variabel dependen, maka ada indikasi adanya Heteroskedastisitas (Ghozali, 2016: 137). Hasil uji heteroskedastisitas dapat dilihat pada tabel 4.5

Tabel 4.5

Uji Hetroskedastisitas

\section{Coefficients $^{\mathrm{a}}$}

\begin{tabular}{|c|c|c|}
\hline Model & $\mathrm{T}$ & Sig. \\
\hline 1 (Constant) & 3,443 &, 101 \\
\hline Leverage & 1,441 & , 152 \\
\hline Likuiditas & $-3,478$ & , 107 \\
\hline Profitabilitas & 1,441 & , 152 \\
\hline Ukuran & 524 & 601 \\
\hline Perusahaan & & \\
\hline CSR & $-4,325$ & , 120 \\
\hline
\end{tabular}

a. Dependent Variable: RES_2

Sumber: Data yang diolah 2018 
Berdasarkan tabel diatas diketahui bahwa nilai signifikan seluruh variabel independen memperoleh nilai probabilitas $>0,05$. Artinya semua variabel pada penelitian ini bebas dari heteroskedastisitas.

\section{Analisis Regresi Linear Berganda}

Tujuannya yaitu menguji pengaruh variabel independen terhadap variabel dependen. Persamaan regresi linear berganda pada penelitian ini yaitu:

$$
\mathrm{ETR}=\alpha+\beta 1 \mathrm{X}_{1}+\beta 2 \mathrm{X} 2+\beta 3 \mathrm{X} 3+\beta 4 \mathrm{X} 4+\beta 5 \mathrm{X} 5+\mathrm{e}
$$

Hasil analisis regresi linear berganda dapat dilihat pada tabel 4.6

Tabel 4.6

Analisis Regresi Linear Berganda

\begin{tabular}{|c|c|c|c|}
\hline \multicolumn{4}{|c|}{ Coefficients $^{\mathrm{a}}$} \\
\hline & & \multicolumn{2}{|c|}{$\begin{array}{c}\text { Unstandardized } \\
\text { Coefficients }\end{array}$} \\
\hline \multicolumn{2}{|c|}{ Model } & B & Std. Error \\
\hline & (Constant) &, 572 &, 093 \\
\hline & Leverage &, 127 & ,048 \\
\hline & Likuiditas &,- 043 & ,013 \\
\hline & Profitabilitas & ,411 & , 185 \\
\hline & $\begin{array}{l}\text { Ukuran } \\
\text { Perusahaan }\end{array}$ &,- 006 & ,004 \\
\hline & CSR &,- 396 & 076 \\
\hline
\end{tabular}

Sumber: Data yang diolah 2018

Dari hasil tabel diatas yang diinterprestasi adalah kolom B, baris pertama menunjukkan konstanta $(\alpha)$ dan baris berikutnya menunjukkan konstanta variabel independen. Dengan demikian dapat dirumuskan persamaan regresi linear berganda yaitu sebagai berikut:

$\mathrm{ETR}=\alpha+0,127-0,043+0,411-0,006-0,396+\mathrm{e}$

\section{Pengujian Hipotesis}

\section{Uji Signifikansi Parameter Individual (Uji t)}

Pada dasarnya pengujian ini menunjukkan seberapa jauh pengaruh satu variabel independen secara individual dalam menerangkan variabel dependen (Ghozali, 2016: 97). Hasil uji t dapat dilihat pada tabel 4.7

Tabel 4.7

\section{Uji T}

Coefficients $^{\mathrm{a}}$

\begin{tabular}{|c|c|c|c|c|c|}
\hline \multirow[b]{2}{*}{ Model } & \multicolumn{2}{|c|}{$\begin{array}{c}\text { Unstandardized } \\
\text { Coefficients }\end{array}$} & \multirow{2}{*}{$\begin{array}{c}\begin{array}{c}\text { Standardi } \\
\text { zed } \\
\text { Coefficien } \\
\text { ts }\end{array} \\
\text { Beta }\end{array}$} & \multirow[b]{2}{*}{$\mathrm{t}$} & \multirow[b]{2}{*}{ Sig. } \\
\hline & B & $\begin{array}{l}\text { Std. } \\
\text { Error }\end{array}$ & & & \\
\hline 1 (Constant) &, 572 &, 093 & & 6,169 &, 000 \\
\hline
\end{tabular}




\begin{tabular}{l|r|r|r|r|r|} 
Leverage &, 127 &, 048 &, 211 & 2,661 &, 009 \\
Likuiditas &,- 043 &, 013 &,- 258 & $-3,243$ &, 001 \\
Profitabilitas &, 411 &, 185 &, 166 & 2,224 &, 028 \\
Ukuran &,- 006 &, 004 &,- 124 & $-1,727$ &, 086 \\
Perusahaan &,- 396 &, 076 &,- 379 & $-5,248$ &, 000 \\
CSR &
\end{tabular}

a. Dependent Variable: Agresivitas Pajak

Sumber: Data yang diolah 2018

\section{Uji signifikansi simultan (uji F)}

Uji F bertujuan untuk mengetahui pengaruh apakah semua variabel independen yang dimaksud mempunyai pengaruh keseluruhan terhadap variabel dependen (Ghozali, 2016: 96). Hasil uji F dapat dilihat pada tabel 4.8

Tabel 4.8

Uji F

ANOVA $^{\mathrm{a}}$

\begin{tabular}{|l|r|r|r|r|r|}
\hline Model & $\begin{array}{r}\text { Sum of } \\
\text { Squares }\end{array}$ & Df & $\begin{array}{r}\text { Mean } \\
\text { Square }\end{array}$ & F & Sig. \\
\hline $1 \quad$ Regression &, 441 & 5 &, 088 & 11,049 &, $000^{\mathrm{b}}$ \\
Residual & 1,133 & 142 &, 008 & & \\
Total & 1,573 & 147 & & & \\
\hline
\end{tabular}

Sumber: Data yang diolah 2018

Berdasarkan tabel diatas diketahu nilai probabilitas sebesar 0,000 artinya seluruh variabel independen pada penelitian ini secara bersama-sama (simultan) mempunyai pengaruh yang signifikan terhadap variabel dependen.

\section{Uji Koefisiensi Determinasi (Uji R²)}

Koefisien determinasi $\left(\mathrm{R}^{2}\right)$ untuk mengukur seberapa jauh kemampuan model dalam menerangkan variasi variabel dependen. Nilai koefisien determinasi yaitu antara nol dan satu (0-1). Nilai $\mathrm{R}^{2}$ yang kecil artinya kemampuan variabel independen dalam menjelaskan variasi variabel dependen amat terbatas (Ghozali, 2016: 95). Hasil uji koefisien determinasi dapat dilihat pada tabel 4.9

\section{Tabel 4.8}

Uji Koefisien Determinasi

\begin{tabular}{|c|c|c|c|}
\hline \multicolumn{4}{|c|}{ Model Summary } \\
\hline $\begin{array}{l}\text { Mode } \\
1\end{array}$ & $\mathrm{R}$ & R Square & Adjusted R Square \\
\hline 1 &, $829^{\mathrm{a}}$ & ,780 & ,755 \\
\hline
\end{tabular}

Sumber: Data yang diolah 2018 
Berdasarkan tabel diatas diketahui nilai Adjusted $R^{2}$ sebesar 0,780, artinya Adjusted $R^{2}$ mampu mengidentifikasikan kontribusi variabel independen terhadap variabel dependen sebesar $78 \%$ sedangkan sisanya $22 \%$ dijelaskan oleh variabel lain yang tidak termasuk dalam model regresi.

\section{Pembahasan}

\section{Pengaruh leverage terhadap agresivitas pajak}

Berdasarkan hasil uji t diketahui nilai t_hitung sebesar 2,661 dengan nilaii signifikansi 0,009 yang berarti nilai sig $<0,05$, maka $\mathrm{H} 1$ diterima jadi kesimpulannya variabel leverage berpengaruh positif terhadap agresivitas pajak.

Perusahaan menggunakan hutang untuk memenuhi kebutuhan operasional maupun investasi. Hutang dimanfaatkan oleh perusahaan untuk meminimalkann beban pajak yang harus dibayar oleh perusahaan, karena hutang akan menimbulkan beban bunga, tindakan tersebut cenderung mengarah dalam tindakan agresivitas pajak. Keputusan tersebut diambil perusahaan karena semakin tinggi hutang maka akan menimbulkan beban bunga yang tinggi dan akan mendapatkan insentif pajak berupa potongan atas bunga pinjaman tersebut.

Hasil penelitian sejalan dengan penelitian yang dilakukan oleh Hanik dan Fadjrih (2016) menyatakan bahwa leverage berpengaruh terhadap agresivitas pajak. Semakin tinggi leverage perusahaan maka semakin tinggi juga agresivitas pajak. Namun berbeda dengan penelitian yang dialakukan Fitri Anita (2015) menyatakan bahwa leverage tidak berpengaruh terhadap agresivitas pajak.

\section{Pengaruh likuiditas terhadap agresivitas pajak}

Berdasarkan hasil uji t diketahui nilai t_hitung sebesar -3,243 dengan nilai signifikansi 0,001 artinya nilai sig $<0,05$, maka $\mathrm{H} 2$ diterima. Jadi, kesimpulannya variabel likuiditas berpengaruh negatif dan signifikan terhadap agresivitas pajak.

Perusahaan yang mempunyai likuiditas tinggi artinya arus kas perusahaan dalam kondisi yang baik sehingga perusahaan tidak enggan dalam memenuhi kewajibannya untuk membayar pajak atau perusahaan memiliki agresivitas pajak yang rendah, hal ini sesuai dengan teori agensi. Sebaliknya, jika perusahaan memiliki tingkat likuiditas rendah maka cenderung melakukan tindakan agresivitas pajak.

Penelitian ini didukung dengan penelitian oleh Fitri Anita (2015) yang menyatakan likuiditas memiliki pengaruh terhadap agresivitas pajak. Tetapi berbeda dengan penelitian dari Tiaras dan Wijaya (2015) menyatakan bahwa likuiditas tidak berpengaruh terhadap agresivitas pajak.

\section{Pengaruh profitabilitas terhadap agresivitas pajak}


Berdasarkan hasil uji t diketahui nilai t_hitung sebesar 2,224 dengan nilai signifikansi 0,028 artinya nilai sig < 0,05, maka H3 diterima. Jadi, kesimpulannya variabel profitabilitas berpengaruh positif dan signifikan terhadap agresivitas pajak.

Jika perusahaan memiliki profitabilitas tinggi maka nilai dari laba perusahaan juga akan tinggi. Perusahaan yang mempunyai profitabilitas tinggi maka pajak yang dibayarkan oleh perusahaan juga tinggi, hal ini mendukung teori agensi. Jadi, perusahaan yang memiliki tingkat profitabilitas tinggi memiliki peluang untuk melakukan tax planning dengan mengurangi jumlah beban pajak yang akan dibayarkan, hal tersebut merupakan tindakan agresivitas pajak.

Penelitian ini didukung dengan penelitian yang dilakukan oleh Luke dan Zulaikha (2016) menyatakan bahwa profitabilitas berpengaruh positif signifikan terhadap agresivitas pajak. Namun berbeda dengan penelitian yang dilakukan oleh Fikriyah (2013) yang menjelaskan bahwa ROA tidak mempunyai pengaruh signifikan terhadap agresivitas pajak. Karena semakin tinggi tingkat profitabilitas maka tingkat agresivitas pajak dari suatu perusahaan akan menurun.

\section{Pengaruh ukuran perusahaan terhadap agresivitas pajak}

Berdasarkan hasil uji $\mathrm{t}$ diketahui nilai t_hitung sebesar -1, 727 dengan nilai signifikansi 0,086 artinya nilai sig > 0,05, maka H4 ditolak. Jadi, kesimpulannya variabel ukuran perusahaan tidak berpengaruh terhadap agresivitas pajak.

Perusahaan yang besar pasti mampu memanfaatkan sumber daya nya untuk membuat suatu tax planning yang baik. Tetapi tidak semua perusahaan selalu memanfaatkan peluang tersebut untuk melakukan tax planning, karena ada batasan yang kemungkinan perusahaan tersebut akan menjadi perhatian khusus oleh fiskus.

Karena perusahaan yang besar sama dengan perusahaan kecil, selalu dikejar oleh fiskus apabila melanggar ketentuan dalam pembayaran pajak. Sehingga dapat disimpulkan bahwa kedua pandangan mengenai bentuk ukuran perusahaan terhadap agresivitas pajak tidak dimanfaatkan oleh perusahaan.

Penelitian ini didukung dengan penelitian Fitri Anita (2015) yang menjelaskan bahwa ukuran perusahaan tidak memiliki berpengaruh terhadap agresivitas pajak. Namun berbeda dengan pendapat Luke dan Zulaikha (2016), menyatakan bahwa Ukuran Perusahaan (Size) berpengaruh posistif terhadap Agresivitas Pajak.

Pengaruh corporate social responsibility terhadap agresivitas pajak 
Berdasarkan hasil uji $\mathrm{t}$ diketahui nilai t_hitung sebesar -5,248 dengan signifikansi 0,000 artinya nilai sig < 0,05 maka H5 diterima. Jadi, kesimpulannya variabel corporate social responsibility berpengaruh negatif dan signifikan.

Karena dalam teori legitimasi semakin tinggi tingkat pengungkapan corporate social responsibility oleh suatu perusahaan maka semakin rendah tingkat agresivitas pajak oleh perusahaan. Landasan yang menjadi dasar tanggung jawab sosial adalah bagaimana perusahaan tersebut bersimpati pada lingkungan, terhadap dampak yang diakibatkan oleh aktivitas operasional perusahaan.

Hasil penelitian ini sejalan dengan penelitian yang dilakukan Hanik dan Nur Fadjrih (2016) menunjukkan bahwa CSR berpengaruh signifikan dan negatif terhadap agresivitas pajak. Namun berbeda dengan penelitian dari Fitri Anita (2015) menunjukkan bahwa CSR tidak berpengaruh terhadap agresivitas pajak.

\section{KESIMPULAN}

Dari hasil penelitian dan pembahasan yang sesuai dengan tujuan hipotesis maka dapat ditarik kesimpulan bahwa leverage berpengaruh positif terhadap agresivitas pajak. Likuiditas berpengaruh negatif terhadap agresivitas pajak. Profitabilitas berpengaruh positif terhadap agresivitas pajak. Ukuran perusahaan tidak berpengaruh terhadap agresivitas pajak. Corporate social responsibility berpengaruh negatif terhadap agresivitas pajak.

\section{Keterbatasan}

Keterbatasan yang menjadi penghambat yaitu, antara lain sebagai berikut: Peneliti hanya menggunakan logaritma natural total asset sebagi indikator pengukur variabel ukuran perusahaan sehingga hasil yang diperoleh tidak mendukung penelitian dan peneliti hanya menggunakan proksi ETR untuk mengukur tingkat agresivitas pajak.

\section{Saran}

Berikut adalah saran penulis bagi peneliti berikutnya: Sebaiknya peneliti selanjutnya disarankan untuk mengganti indikator untuk mengukur variabel ukuran perusahaan, misal natural logaritma nilai pasar ekuitas perusahaan pada akhir tahun dan sebaiknya menggunakan proksi lain dalam mengukur agresivitas pajak, karena pada penelitian ini peneliti hanya menggunakan proksi Effective Tax Rate (ETR), sehingga agresivitas pajak hanya dilihat dari satu sudut pandang saja, misalnya Cash effective Tax Rates (CETR).

\section{DAFTAR PUSTAKA}

Budi R (2017). Determinan kinerja perusahaan terhadap agresivitas pajak (studi pada perusahaan sektor perbankan yang terdaftar di bei periode 2010-2014). Fakultas ekonomi dan bisnis, Universitas Muhammadiyah Tangerang.

Cooper, Donald R. 1998. Metode Penelitian Bisnis, jilid 2, edisi kelima. Jakarta: Erlangga. 
Fitri A. M. (2015). Pengaruh corporate social responsibility, leverage, likuiditas dan ukuran perusahaan terhadap agresivitas pajak (studi empiris pada perusahaan real estate dan property yang terdaftar di bei tahun 2010-2013). Faculty of Economics Riau University, Pekanbaru, Indonesia.

Ghozali, Imam. 2016. Aplikasi Analisis Multivariete. Semarang: Badan Penerbit Universitas Diponegoro.

Hanik, Fadjrih (2016). Pengaruh Karakteristik karakteristik perusahaan dan corporate social responsibility terhadap agresivitas pajak. Jurnal Ilmu dan Riset Akuntansi. Vol. 5 No. 3. Sekolah Tinggi Ilmu Ekonomi Indonesia (STIESIA) Surabaya.

Hengky Robet M. T (2016). Pengaruh corporate social responsibility dan profitabilitas terhadap agresivitas pajak (studi empiris pada perushaan manufaktur yang terdaftar di bei periode 2012-2014). Universitas Komputer Indonesia.

Kasmir. 2011. Analisis laporan keuangan.Edisi pertama. Cetakan Keempat. Jakarta: PT Raja Grafindo Persada.

Sartono, Agus. 2010.Manajemen keuangan Teori dan Aplikasi. Edisi keempat. cetakan keempat. Yogyakarta: BPFE.

Suandy, Erly. 2006. Perpajakan.Edisi kedua. Jakarta: Salemba Empat.

Suparnyo. 2010. Corporate Social Responsibility Teori dan Praktik. Semarang: Badan Penerbit Universitas Diponegoro.

Tiaras dan Wijaya (2015). Pengaruh likuiditas, leverage, manajemen laba, komisaris independen dan ukuran perusahaan terhadap agresivitas pajak. Jurnal Akuntansi. Vol. XIX No.3. Universitas Tarumanegara Jakarta. 